\title{
ROSES OR BREAD? ANTI-COMMUNIST NARRATION IN FEMINIST READINGS OF ANNA ŚWIRSZCZYŃSKA’s POETRY
}

\author{
KATARZYNA SZOPA
}

\begin{abstract}
The article discusses the question of feminist interpretations of the poetry of Anna Świrszczyńska, one of the most recognized Polish poets of international renown, whose works and activity are often associated with a strong feminist worldview. Many interpreters of Świrszczyńska's poetry did not focus enough on the origin of the poet's feminist attitude, claiming that it was rather exceptional and rare for the period of the Polish People's Republic. Contrary to the narration established by the interpreters of her poetry after 1989, I argue that Świrszczyńska's feminist sensitivity was not an isolated and individual phenomenon, as it emerged in a time of increased women's activity and the development of the socialist project for women's equality deployed in Poland after 1945. I believe that both the political activity of communist women and the grassroots actions taken by the working-class women in the socialist state became the main factors in shaping Świrszczyńska's feminist worldview. The Polish feminist narrative after 1989, however, due to its anti-communist approach to the problem of feminism in the Polish People's Republic, did not include the history of the Polish left-wing women's movement. This results from applying to the Polish history of women's movements 1) liberal notions of feminist agency; 2) Western feminist theories devoid of Marxist paradigm; and 3) a normative definition of feminism understood only in terms of antisystemic activity. By taking into account Świrszczyńska's political and cultural activity, I emphasize the necessity of filling the gaps in the story of Polish women's movement. Such a strategy is inevitably connected with the necessity of remodelling the genealogy of Polish feminism, redefining the notion of agency, and feminism itself.
\end{abstract}

Keywords: socialism, emancipation, feminism, anti-communism, genealogy 


\section{Introduction}

In the 1970s, Anna Świrszczyńska, regarded as one of the most notable Polish poets of the $20^{\text {th }}$ century, published a volume entitled Jestem baba [I Am Baba ${ }^{1}$ (1972). The publication is considered to be one of the most controversial poetry books of that time. In the context of traditional women's poetry, Świrszczyńska's writing - assigned to the so-called second avantgarde - was exceptional not only from the literary point of view, but also primarily in terms of its political inclinations. In her writing, the poet focused on social problems concerning the situation of women, in particular working-class women. Świrszczyńska undermined the traditional view not only on sex but also on the fixed social order whose borders were determined by class and sexual differences (the latter considered in terms of merely biological differences). The poet contests the limits which separate the private from the public sphere, reproductive from productive work, and female forms of activity from politics.

Świrszczyńska's writing gained popularity in the 1990s mostly among feminist theoreticians who either saw her as a precursor of écriture féminine, or used her poetry to create a post-transformation project of emancipation. The interpretation strategies chosen by them reveal the direction feminist discourses in Poland after 1989 have taken. They were all connected by a particular attitude towards the work of their predecessors - party members and communists who participated in deploying the socialist project for women's equality after 1945. The framework of these narrations was based on drawing a clear line separating the contemporary feminist movement from the history of Polish left-wing women's movements.

The aim of this paper is not to reconstruct the main narrative strategies which shaped Polish feminist discourses after 1989. Such work is carried out by researchers of communism, sociologists, and literary scholars, including Małgorzata Fidelis, Magdalena Grabowska, and Agnieszka Mrozik, to whom I refer numerous times. Neither do I intend to provide a deep interpretation of Świrszczyńska's poetry². My goal is rather to follow the discourses in literary criticism which arose around Świrszczyńska's poetry after 1989. It could be observed that the main narrative framework of these discourses consists of two reading strategies: feminist and anti-communist. As a result, Świrszczyńska was read in agreement with the Western paradigm

\footnotetext{
1 There is a difficulty with translating the word "baba" from English into Polish, as it is a term used mainly with a pejorative connotation. The primary meaning of the word is probably "grandmother" or "old woman", although it can also allude to "midwife", "sorceress", or "fortune teller". In Slavic folklore the word also relates to the figure of Baba Yaga (Yegi Baba, Baba Jaga, Baba Jędza), "possibly a pre-Slavic goddess of death and regenerations who, with time and changing socioeconomic conditions, was converted into a malevolent witch" (Oleszkiewicz-Peralba 2015, 7). In the common usage "baba" usually concerns an elderly, uneducated, ugly and dirty woman of rural areas. In this article I decide not to translate the word in order to emphasize the idiosyncratic expression of the title used by Świrszczyńska, and also its performative character.

2 An in-depth discussion of Świrszczyńska's poetry is beyond the scope of this paper. I investigate this problem in depth in my article: Szopa, Katarzyna. 2018. "The Poet of Revolution. Anna Swirszczyńska and the Socialist Project of Women's Equality”. Ślaskie Studia Polonistyczne 2 (forthcoming).
} 
of feminist theories and her poetry was entirely separated from the political and social context in which it had originally emerged. Now, since this construction of the genealogy of Polish women's movements is designed to exclude first of all the activity of communist women, and then also the rich history of self-assemblies of regular women of the Polish People's Republic, mainly peasants and workers in industrial plants, it requires, as I intend to show in my article, a thorough re-evaluation.

\section{The Narration of Absence: Feminism and Communism}

In an interview with Anna Świrszczyńska published in Tygodnik Powszechny in 1964, Wiesław Szymański asked a question in response to the poet's words about the absence of women writers in the literary environment: "May it be concluded that you are a radical feminist?", to which she replied: „Yes, with full support from my husband, who agrees with me completely” (Świrszczyńska and Szymański 1964, 5). It is clear why, considering the reality of the early 1960s, Świrszczyńska strengthens her bold declaration with an anecdote about her husband's support. It was the post-thaw period, marked by the return of conservative narration which assumed women's natural affiliation to home and their maternal duties. That current was accompanied by the reactions of the government of those days, such as depriving women of their jobs or downgrading them, retracting the Polish Women's League and Women's Departments from workplaces, and directing women's activity at the so-called "tailoring and sewing workshops". The emancipation of women was to blame for the growing number of divorces (Grabowska 2018, 80), and the image of a 1950s working-class woman was presented as masculinized, ridiculed, and twisted (Fidelis 2015, 265), as an attack on Polish tradition and family values. By stressing that she was married, Świrszczyńska obviously tried to avoid the stereotype of a "masculine" feminist. However, it is not the approval of her husband which matters, but the poet's decision to make a public declaration that she considers herself to be a feminist.

However, Polish feminist critics who became interested in Świrszczyńska’s poetry mostly after 1989 hardly ever decided to search for the sources of that surprising declaration. In their studies of Świrszczyńska's oeuvre, the researchers regarded her feminism as a precursory and exceptional phenomenon in times which were mostly considered as "nonfeminist." For example, Małgorzata Baranowska, despite noticing a revolutionary project in Świrszczyńska's poetry and calling it the "avant-garde of women's role poetry or feminist poetry," still considered the revolution as "one-person" (Baranowska 1995, 263). Ewa Kraskowska acknowledged that the poet "wandered alone" in times when "feminism was an almost unknown phenomenon in Poland" (Kraskowska 2015, 33). Anna Legeżyńska saw in Jestem baba [I Am Baba] the "seed of Polish feminism (which is to break out in twenty-five 
years!)” (Legeżyńska 1997, 184). Hanna Jaxa-Rożen repeated after Baranowska that I Am Baba is a "one-person revolution of the 70s" which "solitarily went ahead of its time" (Jaxa-Rożen 2011, 252). Świrszczyńska’s monographer, Renata Stawowy, put it similarly by stating that the poet's feminism was “a self-generated and secluded phenomenon in the Polish People's Republic," and that the "threads connecting her views with the tradition of the Polish emancipation movements" were "feeble" (Stawowy 2004, 152). Another monographer of Świrszczyńska's poetry, Agnieszka Stapkiewicz, was a rare exception, as she attempted to determine the source of the poet's feminist awareness and eventually located it in the experience of the 1905 revolution in which Świrszczyńska's father took part. Almost all the researchers completely passed over the social and political events of the 1960s and 1970s in silence; these were the times when Świrszczyńska published those of her poetry books where she reveals her feminist world view.

Reading Świrszczyńska in the 1990s was limited to speculations about what women's literature or poetry should mean. The political significance of this poetry, which focused mostly on problems related to women's reproductive work, was erased entirely. Hence, the researchers wondered if Świrszczyńska could be classified as an écriture féminine poet (Borkowska 1995; Nasiłowska 2004), but they did not search for the actual roots of her feminist worldview. Following the Western methodology and feminist theories, the interpreters of Świrszczyńska's poetry focused on the bodily aspects of her poetry so much that the discourse on the body they created, in fact, turned out to be "dis-embodied". Consequently, Świrszczyńska's poetry became only a pretext to discuss universal experiences of "femininity", even though in her poetry the woman's body bears numerous marks of social, cultural, economic, and political situatedness, as it is mostly the body of an old working-class woman or a village-dweller from the times of Władysław Gomułka. Tearing Świrszczyńska’s poetry away from the original context was accompanied by the application of Western feminist theories, which were also torn away from their political and social roots (see Delphy 1995) ${ }^{3}$.

In her article entitled Feministyczne rozrachunki z PRL-em [Feminist settling of accounts with The Polish People's Republic], Agnieszka Gajewska summarizes this reading strategy. She notes that according to Świrszczyńska's readers “there was no feminism in the Polish People’s Republic, neither in art nor in theory, nor as a movement. In order to become a feminist, one should read feminist literature [i.e. American - KS], and the second wave would have appeared in Poland in the 1960s if it had not been for the Polish People's Republic" (Gajewska 2010, 464). With this in mind, it could be observed that identity construction of Polish feminism after 1989 is characterized by at least three important questions. The first one refers to the way of

\footnotetext{
${ }^{3}$ French feminist theories, also known as French Feminism (see Delphy 1995), were applied in Poland in a form derived from the Anglo-American interpretations, and served as one of the main methodological frameworks of Polish feminist literary criticism in the 1990s.
} 
constructing the genealogy of Polish feminism after 1989, the roots of which are most often dated back to the pre-war intellectual tradition, and which entirely disregards the grassroots mobilization of women, be they communists, workers, or peasants; the second problem reproduces Western historiography's role models, which show Polish feminism through the prism of three waves, and therefore completely ignores the specific socio-political context which characterized socialist countries; finally, it implies the definition of feminism imposed by the Western - mostly Anglo-American and liberal - feminist methodologies.

I believe that the application of such an interpretative framework to Świrszczyńska's poetry does not stem from researchers' bad intentions but from methodological practice of reproducing the narrative schemes which dominated feminist reflection after 1989. According to Ewa Majewska:

\begin{abstract}
Women and workers must then be erased from the narration about political breakthroughs in the Polish People's Republic, not as a result of the conscious bad intentions of researchers, but due to the habits in political analyses and scientific texts which preclude noticing the agency of the aforementioned groups (Majewska 2018, 74).
\end{abstract}

The crux of those forms of narration, as shown by Magdalena Grabowska, is anti-communism. In her book entitled Zerwana genealogia: Driałalność społeczna i polityczna kobiet po 1945 roku a wspótczesny polski ruch kobiecy [Broken Genealogy. Women's Social and Political Activity after 1945, and the Contemporary Women's Movement in Poland following the way of constructing feminist historiography in Poland after 1989, Grabowska distinguishes three types of narration: of absence, of convergence, and of anti-communism. The first one assumes that there is no such phenomenon as an Eastern European feminism; the second presents post-socialist women's movements as lagging behind the Western ones; the last shows communism as the phenomenon responsible for the absence of emancipation movements in Eastern Europe (Grabowska 2018, 19). Significantly, Agnieszka Mrozik also proves that the history repressed from the collective memory of Polish feminism is precisely the activity of communists from Stalinist times, namely of women in charge, actively co-creating the foundations of the postwar system. Not only does Polish feminism deny their activity as a valid part of its own movement, but, above all, it uses their history to build its own founding myths in order to legitimize the mainstream national-liberal narration (Mrozik 2012, 52; 2014; 2017a).

Thus, feminist "broken genealogy" concerns not just the phenomenon of dissociating the one feminist formation from the other, but above all, the phenomenon of dissociating feminism from communism. Such a narration results in the impossibility of reconciling the image of a communist with the image of a feminist or emancipationist (Grabowska 2018, 53). As Grabowska states: 
The effect of these processes is feminism which forgets its own genealogy, telling a story of the absence of egalitarian traditions in Poland, a story which is unconvincing from the point of view of feminist practice. The movement which relates itself to historical narrations of Western feminisms, the movement with the vision of itself (individual or collective identity), remains elitist and unconvincing in a great degree (Grabowska 2018, 173).

While I do not claim that the interpretative perspective of Świrszczyńska’s poetry proposed by feminist literary scholars in the 1990s should be completely rejected, I emphasize the necessity of complementing the story by filling in gaps and contexts. Such a strategy is inevitably connected with the necessity of: 1) remodelling the genealogy of Polish feminism, 2) redefining the notion of agency, and 3) feminism itself.

\section{Genealogies of Feminism or Genealogies of Feminists?}

The origins of Polish feminism are usually dated back to the early 1980s when the events involving early Solidarity took place. Coincidentally, it is also a time when the book edited by Teresa Hołówka Nikt nie rodzi sie kobieta [One is Not Born a Woman] (1982) that introduced feminist theories to Polish humanities was published. Gajewska asks, however: 'Wasn't there anything before? Before the second samizdat emerged and revived the patriotic-romantic ethos, were feminist traditions absent and were the connections between educated women and emancipation movements of the interwar period entirely torn?” (Gajewska 2010, 467). In response to this question, Gajewska draws the reader's attention to the fact that the period between 1945 and 1982 is mostly ignored. She points at two dates essential for Polish feminism: April 27th 1956 when abortion was legalized, and March $8^{\text {th }}$, 1968, the date of bloody suppression of student protests and anti-Semitic persecution.

However, one may ask if the Polish feminist tradition amounts merely to the antisystemic fight of educated women from intellectual circles. Why do we need to limit women's activity in the Polish People's Republic only to the Polish Women's League and the Association of Rural Women? And finally, is the history of women in the Polish People's Republic, as suggested by Gajewska, a history of failure? As Małgorzata Fidelis argues in her book Women, Communism, and Industrialization in Postwar Poland (2010 [2015]), definitely not. Fidelis reconstructs a different story of Polish feminism by placing the grassroots movement of women working in factories and industrial plants in its centre and by showing that women constituted numerous groups of active subjects which created the post-war society.

It is thus crucial to pose a question about the genealogy of Polish feminism. As Agnieszka Graff aptly notes, "the genealogy of feminism is not just the genealogy of feminists - feminism as a political community and cultural project seeks for wonderful, empowered women in the 
past, not only feminists" (Graff 2014, 194). Despite that remark, Graff focuses her attention solely on women's organizations and not on the stories about self-assemblies of ordinary women, and thereby, she validates the normative definition of feminism: not only does she disregard the activity of party members and communists, but she also overlooks protests and strikes initiated by the working-class women in the history of Polish women's movements. She writes:

I am interested in this matter as a fragment of Polish history, a fragment of women's history, but it does not convince me as an identity story of contemporary feminism, let alone of my own. These are not my roots. (...) Intellectually, emotionally, and biographically my roots arise from the firm opposition against the Polish People's Republic. I am not convinced at all by the idea that people who co-formed the regime, women of the Polish United Workers' Party, are my ancestors. They are not! (Graff 2014, 189-190)

Diminishing the role of Communists in the process of emancipating Polish women results from the history of their entanglement in building the machinery of the state during the Stalinist rule, which is commonly recognized as criminal. But the fact is that the Polish Women's League and the Association of Rural Women both date back to the period before the First World War, and simply continued their activity after 1945 by focusing on supporting women's employment and by organizing training to develop their skills (Nowak 2005). However, in the post-thaw period, the state propaganda was trying to erase the inconvenient memory of Stalinist times, along with the figure of the Jew and the emancipated female worker. Conservative sex politics, which deepened the traditional division of gender roles, became more popular (Gajewska 2010, 475). In consequence, the emancipatory actions of the Polish Women's League seemed to be limited, as the only thing they enabled women to do was to combine their unwaged work at home with their paid work.

Thus, the activity of the League after 1989 was regarded as "superficial" and "counterfeit," and the privileges which women had in the Polish People's Republic as imposed on them. Graff argues that "Polish women were mostly affected by the fact that there were nursery schools and pre-schools in the Polish People's Republic (...), but this is not feminism in action, nobody fought to achieve it - those were the elements of the welfare state, which that socialist patriarchate gave to women" (Graff 2014, 192).

Graff's view on the history of the communist activity of women is not rare. In comparison, Sławomira Walczewska summarizes the period of activity of the Polish Women's League as follows: 
The Polish Women's League was an institution created by the ruling communist party. Despite the conditions in which it came to life, despite the methods it applied and its concept of emancipation, it called itself a women's organization which represented their interests and was a forum for all Polish women. The effect of 45 years of its existence, still visible today, is women's political inaction, their inability to organize themselves and protect their collective interests (the anti-abortion act is a case in point) (Walczewska 1993).

Walczewska thus argues that the fact that the Polish Women's League was the only women's organization in the Polish People's Republic would prevent women from creating other groups and organizations. According to Walczewska, that, in turn, would result in breaking with the tradition of the pre-war women's movement, reducing all groups of women to an "undifferentiated mass," and identifying them with communist activists. "At the same time", she continues, "the achievements of the so-called »bourgeois« women's movement, which fought for women's rights in Europe even before communist parties emerged, were passed over" (Walczewska 1993). Significantly, Graff presents her view on feminist genealogy in a similar way:

I believed that (...) feminism came from John Stuart Mill, whereas its variant, which draws from Engels and Rosa Luxemburg, seemed a form of aberration to me. Luckily for me, this story of mine is older, as Mary Wollstonecraft and John Stuart Mill noticed the poorer situation of women a bit earlier than Engels did (Graff 2014, 190).

One might clearly notice in both statements several features of anti-communist political narrations. First of all, feminism is not considered a mass social movement but is limited to the activity of women from the privileged intellectual classes. Secondly, the researchers claim that feminism has a single common "beginning". Finally, they adopt the paternalistic perspective which is typical for post-transformation narrations and which assumes that women's agency in the Polish People's Republic was "superficial" and imposed by the communist authorities. By writing that it was the activity of the Polish Women's League that increased the level of political inaction of Polish women, which eventually resulted in accepting the anti-abortion act in 1993, Walczewska solidifies the stereotypes of the "inactivity" of generations of women raised in the Polish People's Republic and their inability to adapt to the new post-socialist reality. This division of social groups into the "active" and the "passive" side corresponds to the (ideological) division between the "new world" and "communist pathology". Monika Bobako describes that way of thinking as "racialization", which is based on essentialising, naturalising, and reifying the cultural features of a given social group in order to justify social inequalities (Bobako 2011). 
Similarly, Mrozik also notices the division of women into "good" and "evil" according to the role model of heroism-martyrdom narration (Mrozik 2017). In such narrations, as Mrozik observes, good and heroic women who oppose the communist party are usually contrasted with malevolent women, mainly the party members, who collaborate with the authorities. This division is reflected in the way of thinking about the communist system and the post-transformation period. It also validates the return of two narrations in the 90s: the conservative, with the figure of the Polish Mother at its centre, and the misogynistic, "reflected in the refusal to acknowledge the autonomy and political agency of communists and pushing them to the area of women's biology, instincts, urges" (Mrozik 2014) with the image of communist women presented as "demonic" (Mrozik 2017b).

All things considered, it seems evident that the mainstream history of Polish women's movements is dominated by the Western narration of liberal feminism. The history of Polish feminism is regarded solely through the prism of "the narration of success", as the struggle of women who originate from intellectual circles and participate only in the resistance movements. Mrozik states that the inability to go beyond the frames of anti-communist discourse presents the history of women's movements in Poland as a story of exclusion:

\footnotetext{
Weaving this pattern from values such as patriotism, the ethos of a community worker (especially locally) or women's ethics of care (mostly seen in the private, family area), The Congress of Women - calling itself the proponent of women's issues in Poland actually made the script of traditional Polish women's activity valid, as well as a particular form of agency: of a unit or a small community, acting without any help from the state, against all odds. At the same time, it displaced other models of women's agency and their "being in the world" out of sight, as well as the concepts of women's subjectivity other than the one realized in the space between family, market, and nation (Mrozik 2014).
}

Such a narrative strategy not only ignores entirely the activity of communists and party members, but also fails to recognize the grassroots activity of ordinary women - i.e., peasants and factory workers - who organized strikes and forced the communist authorities to compromise dozens of times.

\section{Feminist Methodologies: A Socialist Project of Women's Equality}

Where would Świrszczyńska's (and her husband's!) feminist worldview come from if it is agreed that there was no feminism in the Polish People's Republic? My thesis is that, contrary to the narration proposed by the interpreters of her poetry after 1989, Świrszczyńska's feminist sensitivity was not an isolated and individual phenomenon since it occurred during increased 
women's activity in the Polish People's Republic and in the context of turbulent social and cultural changes. I believe that the socialist project of women's equality deployed in Poland after 1945 became the main factor in shaping the poet's feminist worldview.

Jestem baba [I am baba] is divided into two parts: the first one is mainly focused on the daily reality of ordinary women and their place in the patriarchal society and family. Świrszczyńska in a very naturalistic fashion introduces into her poetry everyday problems such as physical and emotional violence against women in the traditional family, alcoholism, poverty, alienation of elderly women, etc. What I consider the most important aspect of her oeuvre is the manner in which she emphasizes the importance of reproductive labour, such as childbearing, and household labour: "born under a black star / we gave birth to the world" (Pod czarna gwiazda [Under a black star]). In the second part entitled Tray poematy [Three Poetic Cycles], Świrszczyńska changes her narration slightly by taking up two questions, feminine sexuality and love beyond the family relationship. Therefore, in Jestem baba [I am Baba] Świrszczyńska focuses our attention on two originally intertwined spheres that as such cannot be discussed separately: bodily and social, private and public, struggle for identity and politics.

Contrary to the first part, in which there is no female persona as a speaking subject, the second part introduces a self-aware woman as the subject of enunciation. It is no accident that Świrczyńska uses the poem entitled Kobieta rozmawia ze swoim udem [A Woman Converses with her Thigh] as the prologue to the second part and the poem Kobieta mówi o swoim życiu [A Woman Talks about her Life] as its epilogue. Such a strategy reminds us of Luce Irigaray's famous political project of "speaking-as-a-woman." According to Irigaray, in the culture that favours masculine values and subjectivity, women have no language of their own which, as such, would allow them to articulate themselves as political subjects. Thus, in the phallocratic model woman is not recognized as a speaking being, and she has no subjectivity of her own. Irigaray asks:

\footnotetext{
What can be said about a feminine "other" than the one prescribed in, by, phallocratism? How can its language be recovered, or invented? How, for women, can the question of their sexual exploitation be articulated with the question of their social exploitation? What position can women take, today, with respect to politics? Should they intervene, or not, within, or against, institutions? How can they free themselves from their expropriation within patriarchal culture? What questions should they address to its discourse? To its theories? To its scientific disciplines? How can they "put" these questions so that they will not be once more "repressed", "censured"? But also, how can they already speak (as) women?
}

And she immediately gives an answer: 
By going back through the dominant discourse. By interrogating men’s "mastery". By speaking to women. And among women (Irigaray 1985, 119).

To give an illustration of Irigaray's strategy, let's look at the case of Świrszczyńska’s poetry, where she always goes back to the "dominant discourse" of masculine values by demystifying social, cultural, and economic conditions that are conductive to women's oppression. Her emancipatory project is rooted in the project of socialist equality, which pursued the fight for women's rights through politicization of reproductive work and the private sphere. Hence, this project associated equality of rights for women not only with economic equality, but also with the question of feminine identity. For Świrszczyńska, the body, which is subjected to an extensive commentary in the post-transformation period, actually always evokes the social body. As she wrote: "the body of the world should be there in poetry. Aggressively tangible, unique in its diversity, gasping in motion, chaotic in richness, soaking in authenticity. (...) The author must constantly look for direct contact with this life, its corporality" (Świrszczyńska 1973 , 3). By relating simultaneously to the social and the individual body, she reconnects women's individual experience with cultural and political articulation.

What is more, Świrszczyńska introduces into her poetry voices of various women: old, poor, mad, raped, and beaten. She "speaks to other women" and "among women", as highlighted in Irigaray's work. A good example of this strategy could be the poem Siostry zdna [Sisters from the Bottom]:

I have friends in the park,

Old beggar women, crazies.

In their eyes are rings,

which dropped

out precious stones.

We tell each other about our lives

From down below, from the human bottom.

Sisters from the bottom.

We speak fluently in the language of suffering.

We touch each other's hands.

This helps us.

Leaving, I kiss them on the cheek

Delicate as water ${ }^{4}$.

\footnotetext{
${ }^{4}$ Translated by Laura Miller-Purrenhage (Miller-Purrenhage 2014, 75).
} 
By stressing the importance of physical contact, such as a touch or kiss, Świrszczyńska above all restores relationships and kinships with other women and overcomes the alienation which is a condition of women in the patriarchal society. To put it another way, "speaking-as-awoman" already implies speaking collectively with other women. Thus, her poetry is not just a realization of the needs of an individual, but more importantly, an expression of collective struggle and women's engagement in shaping the new order, which would bring together the questions of equality and social justice in the period immediately after the war.

Another key point to remember is that the emancipatory project, for which women as party members, ordinary workers, and communist activists fought after 1945, seemed to be innovative with respect to the situation of women living in the Western countries (Grabowska $2018,240)$. It turns out that women from socialist countries benefited from a larger spectrum of rights in the 50s, before the famous publication entitled The Feminine Mystique by Betty Friedan $(1963)^{5}$ was released. These advantages included the right to abortion, maternity leave, equal wages, free education, health care and perinatal care (Grabowska 2018, 267). According to the reports of the UN and the WIDF (Women's International Democratic Federation) published in the $60 \mathrm{~s}$ and the $70 \mathrm{~s}$, it can also be concluded that "the equality of women was more developed in socialist countries" (Grabowska 2018, 267).

These circumstances influenced the shaping of Świrszczyńska's feminist worldview. She was actively engaged in actions aimed at the improvement of the social and political situation of women in Poland. Jestem baba [I Am Baba] is her answer to the problems of growing domestic violence and alcoholism ${ }^{6}$. These problems were neglected by the authorities in the 1960s and 1970s and seen by them as a result of Stalinist emancipatory politics, which ended in the crisis of family values (Grabowska 2018, 145). Women activists of that period, to a large extent, focused their work on organizing help for aggrieved women. According to Grabowska, their activity brought the phenomenon of violence against women to public attention (for example, through discussion on the question of alimony) and forced the state institutions to act for those women - most of whom were factory workers and women from rural areas - and children who became victims of domestic violence. It does not therefore come as a surprise that Świrszczyńska is an exemplary figure of those times, for she, like no other Polish poet, made

\footnotetext{
${ }^{5}$ However, it is good to recall the words written by Silvia Federici: "Although rarely recognized, the first signals of women's refusal to function as unpaid workers in the home did not come from Betty Friedan's bestseller The Feminine Mystique (1963), but from the struggles of »welfare mothers«, that is women receiving Aid for Dependent Children, in the mid 1960s". The Welfare Mothers Movement was not formed by white middle class women, but primarily by black women, ,asserting the economic value of women's reproductive work and declaring »welfare« a women's right” (Federici 2012, 43, 98).

6 According to Ewa Kraskowska, Świrszczyńska belonged to the Anti-Alcohol Committee and was a supporter of complete abstinence (Kraskowska 2015, 34).
} 
social problems such as alcoholism, infidelity, violence, and exclusion the theme of her poems and exposed the fallacy of separating the private sphere from the public, the aesthetic from the political, the literary from the social.

These findings are crucial for the understanding of the context in which Świrszczyńska wrote Jestem baba [I am Baba]. It is evident, as I argue, that Świrszczyńska's poetry was shaped in the course of the collective practices of women's organizations in the Polish People's Republic. One example of her active engagement in such work practices was her comment published in Trybuna Ludu [People's Tribune] in 1963. The comment concerned Valentina Tereshkova who as the first woman in space was the pilot of "Vostok - 6" spaceship. The situation seems to be all the more unprecedented since Tereshkova also played a major role in creating the international women's movement by participating in the World Congress of Women held in Helsinki in 1969, where she presented her report entitled "Women and work" (Grabowska 2018, 236). In the report, she put forward the main assumptions and strategies for action of the international women's movement and emphasized the necessity of connecting the notion of equality with the analysis of women's economic situation (Grabowska 2018, 237). She also placed the notions connected with women's reproductive work at the centre of her considerations. As a summary of actions taken by women from East European countries, her ideas "formed the foundation for later narrations concerning the equality of the sexes" (Grabowska 2018, 245).

Hence, the solidified division into Western liberal feminism (as a movement which provided us with methodological tools) and Eastern socialist feminism (as a movement which did not influence the formation of gender studies) is not justified here either. On the contrary, "feminist discussions" were conducted throughout the entire period of the Polish People's Republic, and Świrszczyńska was an active participant in them. The character of those discussions may have differed from those which were carried out by the feminist studies in accordance with their Western paradigm due to differences in social and political context, yet the fashion of formulating problems was identical to the dilemmas solved by the Western researchers. Nevertheless, it is baffling that the contemporary Polish researchers assumed that there was no feminist discourse in the socialist countries at all. Their approach only confirms the hegemonic presence of Western theories in Polish feminist reflection. What is more, their disparagement of the left-wing project of rebuilding social ties based on the equality of the sexes was obviously accompanied by the rejection of the Marxist tradition and the implementation of Western feminist methodologies and narrations concerning the history of feminism and its definition. As a result, this dominant approach prevented the generations of contemporary women from telling the story of Polish feminism in a different way, that is, with regard to its geographical, political, economical, and social specificity. 
Having said that, I do not simply claim that we should now reject Western methodologies and simply create our own. It is rather a question of changing the methodological habits and of questioning the manner in which the knowledge in feminist theories is produced. Throughout this process, it is important to choose a strategy which does not eliminate questions about our relationship with particular feminist traditions or the form of the assumed narrative framework. Polish historiographies shaped after 1989 by the national-liberal current have not explored that past enough. And "expelling communists from the historical narration of the women's movement," as Grabowska explains, results in "a constant search for the sources of its legitimization, somehow beyond its own history and experience" (Grabowska 2018, 286).

\section{Definitions: Feminist Agency}

As Clare Hemmings rightly noted, "the desire to be an appropriate feminist subject of politics that underwrites most feminist theory has considerable historiographic power in Western feminist storytelling" (Hemmings 2011, 105). Similarly, anti-communist narration accepted by feminist researchers after 1989 was based on one definition of feminism and women's agency. According to the commonly accepted definition, the "actual" women's agency occurs when it applies to "real power" achieved at the central level, that is, in the area of the state and institutional structures. However, actions taken at the local level - and in particular grassroots actions taken by ordinary women through which women organize themselves collectively and initiate changes - are usually ignored (Grabowska 2018, 155)

Despite that, when we carefully explore the history of women's rebellion and protests, it is easy to spot that women revolt most fiercely in situations in which their status is reduced to reproductive functions. Thus, as Silvia Federici notes, hearth and home - related to women's reproductive work - is one of the most difficult and, at the same time, most effective areas of resistance (Federici 2012). As we can learn from Grabowska and Fidelis, it is no wonder that the communist authorities feared strikes initiated by women the most. It is thus impossible to agree with the thesis that women's political activity after 1945 was "superficial" and imposed by communist authorities. One of Grabowska's interlocutors says: "We enforced the formation of nursery schools and pre-schools alongside the workplaces. (...) We enforced the formation of shops alongside the workplaces so that women could resupply there" (Grabowska 2018 , 139). The action of those women, as well as "the activity of communists does not fit into the existing definitions of feminist agency" (Grabowska 2018, 235).

How should we therefore define feminism? At which moment and where should we localize its origins? Should we agree with the framework of Western narrations that this inaugural status belongs to the first wave of feminism, or should we assume that "there is no 
»beginning " of feminism in the sense that there is no beginning to defiance in women"? (Rowbotham 2014, 16). Sheila Rowbotham suggests that before feminism became a mass social movement there had been actions taken by women that led to the rise of feminism. In other words, "there is a beginning of feminist possibility - even before it is conceived as such. Female resistance has taken several historical shapes" (Rowbotham 2014, 16-17). Therefore, in response to the question "where could an alternative conception of women's potentiality take root?" (Rowbotham 2014, 20) she answers without hesitation - in women's defiance. Even if, in those days, women were not able to politicize their claims and lead to radical transformations with regard to the system of power, their activity over time (Rowbotham begins her narration with the Middle Ages) caused revolutionary riots and led to social changes. Those women questioned their place in the world imposed by men and they sought alternative forms of social existence. "Their history is still almost unknown. They have been regarded as static unchanging factors, as part of the background, as completely passive. They were not in fact submissive" (Rowbotham 2014, 33).

Ewa Majewska calls this form of action a "weak resistance" (Majewska 2018) and Grabowska regards it as a "reactive agency" (Grabowska 2018). Both thinkers propose an alternative to the liberal idea of agency. In the case of communists' actions, the liberal definition ignores the context, the position in time and space, and furthermore, does not fully reflect the complexity of the actions taken and roles played. Grabowska argues that it is very common that women's activity in the Polish People's Republic does not acquire the traits of feminist agency, as it is not characterized by anti-systemic actions or actions taken against the authorities of that time. On the contrary, women co-created those structures, but caused their internal transformations. Thus, "reactive agency" has a strategic meaning on the level of social practice: it is not a gesture of opposition by certain groups or units against the dominating systems of power, but rather actions taken within the structure of the dominant system which eventually result in a social change.

There are numerous examples of such internal dissents in the history of women's movements. For instance, Rowbotham enumerates heretic cults in which women fulfilled their needs, be it emotional or intellectual ones, which they could not fulfil anywhere else. Religious cults slowly morphed into women's collectives which allowed them to spend life out of the institution of marriage (Rowbotham 2014, 21). Between the eighteenth and nineteenth centuries, when some germs of feminist awareness could be observed among women from the privileged social classes, it was, in fact, unnamed women from the lowest social classes who took actions such as riots over lack of food, protests against the increasing prices in Normandy in 1789, public announcement of the complaint list with demands concerning the right to education and access to medical supplies, and pamphlets and petitions concerning divorce and prostitution (Rowbotham 2014, 37): 
Collectively their protest is registered in the eighteenth-century food riot, the traditional manner in which the poor tried to reassert a pre-capitalist moral economy which placed need before profit, and the old community against the new state. The close connection of women to consumption meant that they were figured prominently in these riots (Rowbotham 2014, 33).

Silvia Federici gives the example of women's self-assemblies in Chile and Peru in the 1980s, when, as a part of the collectivization of reproductive work, they formed "common kitchens" (ola communes) in order to cope with the times of increasing crisis and inflation (Federici 2012, 143). Finally, one of Grabowska's interlocutors recalls a similar example of embroidering tray cloths and tablecloths for sale, initiated by activists from the Polish Women's League in the difficult 80s, which helped some women earn means to survive even for an entire month (Grabowska 2018, 151-152). "Such mobilization and mutual help sometimes morphed into income-generating activity that helped some women to survive the painful time of transformation to capitalism after 1989" (Grabowska 2016, 133).

Thus, is it acceptable to nullify those stories or treat them only as anecdotal "fragments of women's history" (Graff 2014, 189) disconnected from the contemporary women's movements? Feminist thinkers show that it was the resistance and dissent, fight and engagement of women over time which laid foundations of the emancipatory movements in the nineteenth and the twentieth century. Women's activity in the Polish People's Republic, which is diminished and commonly perceived as tailoring and sewing courses, should be regarded similarly. It led to substantive changes in the field of family politics, marriage law, and social relations. That activity was ousted and disassembled by Polish liberal feminism after 1989 even though it formed the basics for the post-transformation women's movements.

\section{Conclusions: "Roses and Bread"}

The poetry volume Jestem baba [I Am Baba] prompts an attempt to redefine the narrative norms which defined Polish feminism in the post-transformation period. In my opinion, the common view on women's alleged passivity in the Polish People's Republic, along with the conviction that the working class can only join forces in factories and workplaces, should be reformulated. Consequently, it could lead to the discovery of a new form of women's agency, which begins from the inside.

Thus, contemporary feminist narrations must be transformed by placing the "baba" - a beggar, a housewife, a sex worker, a peasant, a factory worker, a protesting mother of a disabled child, a caretaker of children and elder people, a refugee, an immigrant - in their centre. Feminism, according to Sheila Rowbotham, should form a more inclusive program of political fight which does not divide women into those who fight the war of roses and those who fight 
for bread. She writes that "the woman must of necessity fight for bread and roses, because the material aspect of her exploitation is integrally related to her own consciousness of what she is" (Rowbotham 2014, 114). Świrszczyńska was read by feminist critics in the context of the war of roses, from the perspective of identity politics. The time has come to read her work from the perspective of the fight for bread as well. Świrszczyńska herself would never separate the one domain from the other. She confirms this postulate in her poem Dwie baby [Two babas]: "we immerse in ecstasy / in our babahood / / like two spoons / immerse / in a bowl of hot grits” (Świrszczyńska 1975, 35). 


\section{References}

Baranowska, Małgorzata. 1995. „Szymborska i Świrszczyńska: dwa bieguny codzienności”. Teksty Drugie 3/4: 256-263.

Bobako, Monika. 2011. „Konstruowanie odmienności klasowej jako urasawianie: Przypadek Polski po 1989 roku". Biblioteka Online Think Tanku Feministycznego. http://www.ekologiasztuka.pl/pdf/f0108Bobako2011.pdf.

Borkowska, Grażyna. 1995. „Metafora drożdży: co to jest literatura/poezja kobieca”. Teksty Drugie 3/4: 31-44.

Delphy, Christine. 1995. “The Invention of French Feminism: An Essential Move”. Yale French Studies 87: 190-221.

Federici, Silvia. 2012. Revolution at Point Zero: Housework, Reproduction, and Feminist Struggle. New York: PM Press.

Fidelis, Małgorzata. 2015. Kobiety, komunizm i industrializacja w powojennej Polsce. Trans. Maria Jaszczurowska. Warszawa: Wydawnictwo W.A.B.

Gajewska, Agnieszka. 2010. „Feministyczne rozrachunki z PRL-em”. In Kobiety w polskiej transformacji 1989-2009. Podsumowania, interpretacje, prognozy, eds. Monika FrąckowiakSochańska and Sabina Królikowska. Toruń: Wydawnictwo Adam Marszałek.

Grabowska, Magdalena. 2016. "From Revolutionary Agents to Reactive Actors: The Transformation of Socialist Women's Organizing in Poland from the 1940s through the 1980s". Aspasia 10(1): 126-135.

Grabowska, Magdalena. 2018. Zerwana genealogia: Driatalność spoteczna i polityczna kobiet po 1945 roku a wspótczesny polski ruch kobiecy. Warszawa: Wydawnictwo Naukowe Scholar.

Graff, Agnieszka. 2014. Jestem stad. Warszawa: Wydawnictwo Krytyki Politycznej.

Hemmings, Clare. 2011. Why Stories Matter? The Political Grammar of Feminist Theory. DurhamLondon: Duke University Press.

Irigaray, Luce. 1985. This Sex Which is Not One. Trans. Catherine Porter and Carolyn Burke. Ithaca-New York: Cornell University Press.

Jaxa-Rożen, Hanna. 2011. „Jednoosobowe rewolucje (Anna Świrszczyńska »Jestem baba«; Jadwiga Żylińska »Kapłanki, amazonki i czarownice«)”. In Pisarstwo kobiet pomiędyy dwoma dwudriestoleciami, eds. Inga Iwasiów and Arleta Galant. Szczecin: Wydawnictwo Uniwersytetu Szczecińskiego.

Kraskowska, Ewa. 2015. Poetka i joga. In Laboratorium poezji kobiecej XX wieku, eds. Joanna Grądziel-Wójcik, Jerzy Kaniewski, Agnieszka Kwiatkowska and Tomasz Umerle. Poznań: Wydawnictwo Nauka i Innowacje.

Legeżyńska, Anna. 1997. „Metamorfoza Anny Świrszczyńskiej”. Polonistyka 3: 182-186.

Majewska, Ewa. 2018. Kontrpubliczności ludowe i feministycznne: Wczesna „Solidarnośč” i Cz̨arne Protesty. Warszawa: Instytut Wydawniczy Książka i Prasa.

Miller-Purrenhage Laura. 2014. "Pearls and Toads, Yeast and Froth: Relationships in Anna Świrszczyńska’s Poetry”. Toronto Slavic Quarterly 48: 69-97. 
Mrozik, Agnieszka. 2012. Akuszerki transformacji: Kobiety, literatura i władza w Polsce po 1989 roku. Warszawa: Wydawnictwo IBL PAN.

Mrozik, Agnieszka. 2014. „Poza nawiasem historii (kobiet), czyli po co nam dziś komunistki”. Wakat On-line 3. http://wakat.sdk.pl/poza-nawiasem-historii-kobiet-czyli-po-co-namdzis-komunistki/.

Mrozik, Agnieszka. 2017a. "Komunizm jako pokoleniowa herstoria: Polityki relacji w auto/biografiach polskich komunistek po 1956 roku". In Polityki relacji w literaturze kobiet po 1945 roku, eds. Aleksandra Grzemska and Inga Iwasiów. Szczecin: Wydawnictwo Naukowe Uniwersytetu Szczecińskiego.

Mrozik, Agnieszka. 2017b. "Beasts, demons, and cold bitches: Memories of communist women in contemporary Poland". Baltic Worlds 4: 54-57.

Nasiłowska, Anna. 2004. „Tożsamość kobieca w poezji polskiej XX wieku: Między androgynicznościa a esencjalizmem”. Teksty Drugie 1/2: 103-121.

Nowak, Basia A. 2005. "Constant Conversations: Agitators in the League of Women in Poland during the Stalinist Period". Feminist Studies 3(31): 488-518.

Oleszkiewicz-Peralba, Małgorzata. 2015. Fierce Feminine Divinities of Eurasia and Latin America: Baba Yaga, Käli, Pombagira, and Santa Muerte. New York: Palgrave Macmillan.

Rowbotham, Sheila. 2014. Women, Resistance and Revolution: A History of Women and Revolution in the Modern World. London-New York: Verso.

Stapkiewicz, Agnieszka. 2014. Ciało, kobiecość i śmiech w poezji Anny Świrsz̨raynskiej. Kraków: Universitas.

Stawowy, Renata. 2004. „Gdzie jestem ja sama”: O poezji Anny Świrszcryynskiej. Kraków: Universitas.

Świrszczyńska, Anna and Paweł Wiesław Szymański. 1964. „Rozmowa z Anną Świrszczyńską". Tygodnik Powszechny 28: 5.

Świrszczyńska, Anna. 1973. „Izba tortur, czyli moja teoria poezji”. Kultura 8: 3.

Świrszczyńska, Anna. 1975. Jestem baba. Kraków: Wydawnictwo Literackie.

Walczewska, Sławomira. 1993. „Liga Kobiet - jedyna organizacja kobieca w PRL”. Petnym gtosem 1: http://efka.org.pl/archiwum/index.php?action=p_art\&ID=2. 
Katarzyna Szopa - Assistant Professor of Literary Studies in the Institute of Polish Literary Studies at the University of Silesia in Katowice (Poland). She specializes in literary studies, with an additional research interest in feminist theories, particularly in the philosophy of Luce Irigaray, to which she devoted her $\mathrm{PhD}$ thesis. In 2014 she participated in Luce Irigaray's International Seminar at the University of Bristol, UK. Recently she published a book Poetyka rozkwitania: Różnica ptciowa w filozofii Luce Irigaray [Poetics of Blossoming. Sexual Difference in the Philosophy of Luce Irigaray].

\section{ADDRESS:}

The Institute of Polish Literary Studies

Faculty of Philology

University of Silesia in Katowice

pl. Sejmu Polskiego 1

40-032 Katowice

Poland

EMAIL: szopa.katarzyna2@gmail.com

FUNDING: This work was supported by National Science Centre (grant number: 2018/02/X/HS2/01060).

Citation: Szopa, Katarzyna. 2019. "Roses or Bread? Anti-Communist Narration in Feminist Readings of Anna Świrszczyńska’s Poetry” Praktyka Teoretyczna 1(31): 72-92.

DOI: $10.14746 /$ prt.2019.1.04

\section{AUTOR: Katarzyna Szopa}

TyTuŁ: Chleba czy róż? Antykomunistyczna narracja w feministycznych odczytaniach Anny Świrszczyńskiej

ABSTRAKT: Niniejszy artykuł stanowi analizę feministycznych interpretacji poezji Anny Świrszczyńskiej, jednej z najbardziej rozpoznawalnych poetek w Polsce, której twórczość charakteryzuje wyraźnie feministyczna wrażliwość. Wiele interpretatorek i interpretatorów poezji Świrszczyńskiej nie dociekało, skąd wziął się ów światopogląd poetki, twierdząc raczej, że jak na czasy PRL-u był on zjawiskiem wyjątkowym i rzadkim. W przeciwieństwie do narracji ustanowionej po 1989 roku przez interpretatorki tej poezji, uważam, że feministyczny światopogląd Świrszczyńskiej nie był zjawiskiem indywidualnym i odosobnionym, ponieważ wyłonił się w kontekście wzmożonej aktywności kobiet i w czasie wdrażania socjalistycznego projektu równości kobiet po 1945 roku. Uważam, że zarówno polityczna działalność 
komunistek, jak i oddolne akcje przeprowadzane przez kobiety z klasy robotniczej miały znaczący wpływ na światopogląd poetki. Jednakże kształtująca się po 1989 roku feministyczna narracja zdominowana była przez antykomunistyczny paradygmat i nie uwzględniła w historii polskiego feminizmu lewicowych ruchów kobiecych. Skutkowało to aplikowaniem do historii polskich ruchów kobiecych: 1) liberalnego ujęcia feministycznej sprawczości; 2) zachodnich teorii feministycznych pozbawionych paradygmatu teorii marksistowskich; 3) normatywnej definicji feminizmu ograniczonej wyłącznie do działalności opozycyjnej. Przyglądając się poetyckiej aktywności Świrszczyńskiej, staram się podkreślić konieczność uzupełnienia luk w historii polskich ruchów kobiecych. Strategia ta wiąże się nieodłącznie z koniecznością przemyślenia genealogii polskiego feminizmu oraz redefinicji pojęcia feministycznej sprawczości.

SŁOWA KLUCZOWE: socjalizm, emancypacja, feminizm, antykomunizm, genealogia 